\title{
Gebruik van twee tale in die Daniëlboek
}

\author{
Marius $\mathrm{Nel}^{*}$ \\ (Universiteit van Pretoria)
}

\section{ABSTRACT}

\section{Use of two languages in the Book of Daniel}

The Book of Daniel is characterized by a change of language, from Hebrew to Aramaic to Hebrew (in Dan 2:4b to Aramaic and in Dan 8:1 to Hebrew). What caused the change from the 'sacred' to a 'heathen' language and back? Does the change of language implicate something about the date of origin of the tales (Dan 1-6) and visions (Dan 7-12)? The rabbinical answer to the question and the results of modern research into the book are being investigated. The words "in Aramaic" (in Dan 2:4a) was probably a mistake made by a later scribe when he incorporated a note from the margin into the Biblical text that was used to warn the reader that the language changes at this point. The result is that the text now reads as if the wise men answer the king, who speaks Hebrew, in Aramaic. This leaves the necessary room to speculate that the use of the two languages may have something to do with the process in which the tradition was handed down to the second century writer or redactor of the book.

\section{INLEIDING}

Die taalverandering in die Daniëlboek het oor die eeue tot baie spekulasie aanleiding gegee. By Daniël 2:4a verander die taal vanaf Hebreeus na Aramees, die Aramese gedeelte strek tot by Daniël 7:28. Hierna word die Hebreeuse teks voortgesit.

Wat veral problematies is, is dat die taalverdeling nie met die vormkritiese ooreenkom nie. Vormkrities gesien val die Daniëlboek in twee dele uiteen (Niehr 19983:459-460). Die eerste ses hoofstukke bevat verhale wat aan ' $n$ vreemde koninklike hof afspeel, terwyl die laaste ses hoofstukke vier visioene en gesigte bevat wat te doen het met 'n Jood en Judeërs. Dié artikel ondersoek verskeie moontlikhede wat deur navorsers aangebied is. Daar word by die rabbynse oplossing begin wat die vroegste

Navorsingsassosiaat, Departement Ou Testamentiese Wetenskap, Universiteit van Pretoria. 
antwoord bied. Vir die rabbyne het die gebruik van " $n$ "onheilige" taal soos Aramees in die Bybel hoofbrekens verskaf. Hierna word meer resente navorsers se voorstelle uiteengesit, voordat gepoog word om op redaksiehistoriese gronde ' $\mathrm{n}$ voorstel te maak.

\section{VERANDERING VAN TAAL}

In Daniël 2:4 verander die taal van die vertelling in die Daniëlboek, vanaf die "heilige" na die "alledaagse" taal: Toe het die Chaldeërs met die koning in Aramees gepraat ...

Die oudste gebruik van Aramese woorde in die Ou Testament is waarskynlik in Genesis 31:47. 'n Kort inskripsie op die Milqart-stela (Thomas 1958:239), asook twee Aramese woorde in Genesis 31:47, lewer bewys dat Aramees so vroeg as die helfte van die negende eeu vC neergepen is. 2 Konings 18:26 suggereer dat Aramees in die agtste eeu ' $n$ internasionale taal was. Dit het later die amptelike taal van die Persiese ryk geword. Nie almal stem saam nie. Koch (1980:10) beweer dat Aramees eers sedert 400 gebruik is, en teen die Makkabeërtyd vir die eerste keer omgangstaal onder Jode geword het.

Nehemia 8:8 vertel dat die (Hebreeuse) Tora vir die volk vertaal moes word nadat hulle uit die ballingskap teruggekom het. Hebreeus is nooit weer as spreek- en huistaal herwin nie (Terry 1974:108). LaCocque (1979:39) meld dat ' $n$ Aramese papirus in 1942 ontdek is te Saqqara of Memphis. Dit is " $n$ brief uit Sirië of Palestina waarin die farao om hulp gevra word teen die koning van Babel, wat waarskynlik Nebukadnesar was. Die brief word in 602/603 gedateer, wat dit die oudste bekende Aramese geskrif maak.

Die Qoemranteks van die Daniëlboek wat in 1947 ontdek is, het heelwat debat veroorsaak. Hartman \& Di Lella (1978:73) aanvaar dat 1QDan" "in Aramees" uitlaat. Die skrywers maak egter waarskynlik " $n$ fout. Ondersoek van die manuskrip toon dat die rol hier beskadig is. Daar is voldoende ruimte in die beskadigde manuskrip vir die woorde "in Aramees", soos dit in die Massorete-teks voorkom. Daar moet aanvaar word dat "in Aramees" ook in die Qoemranteks voorkom.

Die Aramese vertelling strek tot aan die einde van hoofstuk 7 (vv 4b7:28). Die oorgang van Daniël $7: 18$ na $8: 1$ vind sonder enige verduideliking plaas. 
Die gebruik van Aramees in die heilige geskrifte van die Jode het vir die rabbyne hoofbrekens verskaf. Hoe kon ' $n$ geïnspireerde man so ' $n$ taal besig? En hoe kon 'n boek in die kanon opgeneem word as dit nie in die gewyde taal is nie?

\section{RABBYNSE OPLOSSINGS}

Die Joodse Talmud, wat verduidelikings van die Tora bevat tot aan die einde van die vyfde eeu nC, skryf die Daniëlboek hoog aan (Baldwin 1978:63). Sagaria ben Kutal skryf in die Misjna dat hy talle kere uit die Daniëlboek vir die hoëpriester voorgelees het in voorbereiding vir Yom Kippur (Yoma 1:6; Danby 1933:163). Sedert die middeleeue het Joodse geleerdes egter die Daniëlboek as minderwaardig begin beskryf, in reaksie op Christene se Messiaanse interpretasie van die boek.

Die oplossing vir die probleem is langs twee lyne deur die rabbyne aangebied. Eerstens word die Aramese dele as ' $\mathrm{n}$ Targum beskou. ' $\mathrm{n}$ Targum word beskryf as "n verklaring van die heilige en gewyde na die ongewyde ter wille van die onverstandige volk (Hartman \& Di Lella 1978:139). Tweedens is die Aramese gedeeltes toegeskryf aan die ontstaan daarvan in ' $n$ onrein land (Anderson 1984:14; Collins 1991:153). Dit is moontlik dat die rabbyne se onbehae met die gebruik van die Aramese taal in die Daniëlboek ook te doen mag hê met die plek wat die rabbi's aan die boek in die kanon toeken. Koch (1980:34) en Collins (1993:82) meen dit is die rede waarom die Joodse rabbi's die Daniëlboek onder die derde deel van die kanon, die Ketubim geplaas het.

\section{DATERING VAN BOEK}

Navorsers het die voorkoms van twee tale in die boek benut en verskeie pogings aangewend om die Daniëlboek te dateer op grond van die gebruik van die twee tale wat daarin voorkom. Die twee tale sou dan 'n bydrae lewer om uitspraak oor ' $n$ belangrike inleidende kwessie te lewer: het die Daniëlboek as " $n$ eenheid ontstaan, of kom die verhale (Dan 1-6) uit 'n vroeër era?

Geen oortuigende gevolgtrekkings het egter daaruit gekom nie (Ackroyd 1953:113-132 en Van Beek 1962:763-4). Baldwin (1978:30) se opsomming is van pas: "...it is precarious to attempt to establish the date of a book on linguistic evidence, especially if the amount of comparative material is very limited, as is still the case with the Hebrew and Aramaic of the Old Testament". Aalders (s.a.:31) toon aan "de taalontwikkeling is 
in het Hebreeuws uiterst langzaam gegaan, zodat het taalverschil bij geschriften die verscheidene eeuwen uit elkander liggen maar zeer gering is". "Clearly the Hebrew of the book cannot confidently be assigned to one century more than another" (Baldwin 1978:31).

' $n$ Sterker argument is uit te maak vanuit die gebruik van vyf en twintig leenwoorde, uit Persies en Grieks, wat voorkom. Die Griekse woorde is die name van drie musiekinstrumente in Daniël 3:5, 7 en 15 (Aalders s.a.:30). Uit Zeno se geskrifte kan afgelei word dat die Griekse taal in Palestina in die dekade na $260 \mathrm{vC}$ in die aristokratiese en militêre kringe van Judaïsme bekend was (vg1 Tripolitis 2002:32).

\section{OPLOSSINGS VIR DIE TWEE TALE-PROBLEEM}

Vir watter rede het die skrywer twee tale in die Daniëlboek gebruik? Navorsers bied verskeie en dikwels uiteenlopende motiverings aan ${ }^{1}$. Die belangrikste standpunte word hier gemeld.

\subsection{Verlies van Hebreeuse gedeelte}

Bevan (1892:24) het reeds die argument gebruik dat 'n deel van die oorspronklike teks wat in Hebreeus was, verlore geraak het. Teen die derde eeu was daar niemand geredelik beskikbaar wat die verlore gedeelte kon hervertaal na Hebreeus nie omdat slegs ' $n$ Aramese vertaling behoue gebly het. Die Aramese vertaling is derhalwe as ' $n$ noodmaatreël in die Hebreeuse teks ingevoeg om die teks volledig te kry, met die bedoeling dat dit op ' $n$ later stadium in Hebreeus vertaal sou word. Die vertaling het nooit gerealiseer nie.

Hierdie verduideliking berus op aannames wat nie op enige feite gegrond is nie, en geen buite-Bybelse bewyse daarvoor bestaan nie. Dit kan dus nie aanvaar word nie.

\subsection{Hebreeus vir Jode, Aramees vir heidene}

' $n$ Volgende oplossing wat aangebied word deur navorsers, en wat ooreenstem met die rabbynse verklaring (vgl 3 hierbo), lê in die bewering

$1 \quad$ Nie alle navorsers gee aandag aan die probleem nie. As voorbeeld bespreek De Villiers (1987:164-170) die kwessie van die eenheid van die boek aan die hand van die vrae: is Daniël ' $\mathrm{n}$ historiese vertelling? En wat beteken dit om te sê dat die visioene apokalipties van aard is, sonder om hoegenaamd op die taalverskil te wys. Baldwin (1978:29) verwys na die probleem, maar verkies dan om eerder oor die datum van die Hebreeuse en Aramese taalgebruik te besin. 
dat die Aramese taal in die Daniëlboek gebruik word wanneer gedeeltes bespreek word wat spesifiek op die heidene gerig is (Charles 1929:113). Hier word spesifiek na die "profesieë" van die tweede en sewende hoofstukke verwys, wat dan teen vreemde nasies gerig sou wees. Hebreeus is hiervolgens gebruik vir gedeeltes wat weer op die Joodse volk van toepassing is, en wat volgens dié standpunt na die "profesieë" van die laaste hoofstukke (hfste 8-12) verwys. Die skrywer gebruik 'n internasionale taal (lingua franca) vir die deel wat 'n boodskap vir nieJode, die nasies, bevat (Lenglet 1972:174).

Hierdie standpunt hou slegs water as die onderliggende veronderstelling daarvan aanvaar word, naamlik dat die boek "profeties" van aard is. "Profeties" word dan geïnterpreteer in terme daarvan dat die droom of gesig inligting bevat waarmee Daniël die toekoms voorspel of openbaar maak. Moderne navorsers aanvaar egter dat die Daniëlboek se "profetiese" waarde slegs daarin lê dat dit tydgebonde bemoedigende woorde vir Jode van die tweede eeu $\mathrm{vC}$ bevat.

Die probleem bly steeds: wat van die verhaal in Daniël 1? Dié verhaal lê op dieselfde vlak as die res van die verhale in Daniël 2-6. 'n Verdere vraag wat gestel moet word, is: wat van Daniël 7? Dit pas nie by Daniël 1-6 in nie. Selfs ' $n$ oppervlakkige ondersoek na die boek toon dat die boek in twee dele uiteenval: die verhale in Daniël 1-6 en die visioene in Daniël 7-12. Indien enige van dié dele in een en die ander in die ander taal was, sou dit sin gemaak het deurdat die boek op vormkritiese gronde verdeel is. Maar die taalverdeling gaan oor die grense wat binne die boek geld, sodat vyf-sesdes van die verhale en ' $n$ kwart van die visioene in Aramees is. Dié antwoord, dat Aramees gebruik is ter wille van heidene se verstaan van die gedeeltes van die boek wat op hulle van toepassing is, is nie geldig nie.

' $\mathrm{n}$ Laaste probleem is dat baie van die Jode in die tweede eeu $\mathrm{vC}$ se huistaal Aramees was, terwyl Hebreeus as "major vehicle of literature" gedien het (Van Beek 1962:714). Hebreeus was die sakrale taal wat aan die tempeldiens en heilige geskrifte verbind was, terwyl Aramees die gewone taal van die man op straat was. Die argument dat Aramees ter wille van heidene of heidense nasies gebruik is, gaan dus nie op nie.

\subsection{Aramese gedeeltes vir nie-Jode}

' $n$ Argument wat met die vorige (5.2) verband hou, is dat die gedeelte wat nie-Jode sou interesseer, in Aramees geskryf is, terwyl die res slegs vir die 
ore en oë van Jode bedoel is. Dieselfde vraag geld egter steeds: wat dan van hoofstuk 1, wat as sleutel tot die boek en ook die verhale dien, maar in Hebreeus is? Hoekom maak die skrywer " $n$ verskil tussen die verhaal in Daniël en die verhale in Daniël 2-6? Daniël 1 dien ' $n$ inleidende funksie deurdat dit die leser aan die karakters voorstel en belangrike inligting gee wat die res van die boek ontsluit. Indien die Aramese skrywer dié inligting ontsê word, maak dit die lees van die boek vir hom/haar moeilik, en in sommige opsigte onmoontlik.

' $n$ Beter argument sou wees dat die verhale van bemoediging spesifiek in Aramees geskryf is, sodat die hele (Joodse) volk (wat aanhangers uit ander nasies insluit wat die Joodse godsdiens aanhang) dit kan verstaan. Die implikasie kan dan wees dat die visioene met die oog op ' $n$ meer gesofistikeerde en geleerde gehoor geskryf is, wat Hebreeus magtig is.

\subsection{Bedoeling van skrywer}

'n Goeie rede word deur Koch (1980:49) vermeld: dit mag wees dat die skrywer dit so bedoel het, maar nie die moeite gedoen het om sy lesers in te lig hoekom hy dit so doen nie (Eissfeldt 1974:516 gebruik dieselfde argument). Indien dit waar is, sal moderne navorsers nooit weet wat die motivering agter die gebruik van twee tale is nie. Dié inligting het verlore gegaan.

\subsection{Om weerstand onder Jode op te wek}

Indien aanvaar word dat die skrywer/samesteller uit die Makkabese periode kom, word die argument genoem dat hy/sy Aramees aanwend om weerstand onder die mede-Jode op te wek. Die argument maak egter nie sin nie. Hoe sal die gebruik van die vyand se taal in " $n$ boek wat die doel het om Jode te bemoedig, so 'n effek hê? In elk geval, Aramees was nie slegs die taal van die vyand nie maar ook die huistaal van die (meerderheid) Jode.

\subsection{Aparte funksionering van dele van boek}

Die opinie word soms gehuldig dat die verhale eers apart gefunksioneer het, en deur die skrywer oorvertel is (Montgomery 1927:31). Die bundel wat ons tans in die hand het, is saamgestel uit onderskeie bronne. ' $n$ Deel van die verhale waarop die samesteller sy hand lê, was in Aramees. Die skrywer doen nie die moeite om dit te vertaal nie. Hy voeg slegs die verhaal van Daniël 1 wat hy elders in die hande kry en wat in Hebreeus is 
as ' $\mathrm{n}$ inleiding by, asook sy visioene (Dan 7-12) aan die einde (Rowley 1955:273-4). Twee moontlikhede bestaan ten opsigte van die visioene: dat dit dan ook nie die werk van die samesteller nie, maar " $n$ produk wat hy/sy leen en aan sy werk voeg; of dat die visioene die samesteller se oorspronklike werk is, en dat hy/sy die verhale inkorporeer om ' $n$ historiese agtergronde vir sy/haar visioene te gee wat legitimiteit daaraan kan verleen deur die naam van die wyse Daniël te gebruik wat teen die agtergrond van die Babiloniese ballingskap geplaas word.

Die veronderstelling van dié argument is dat die samesteller die verhale net so invoeg, sonder enige redaksionele bywerkings. Dat die skrywer egter redaksionele bywerkings doen, kan bewys word deur te verwys na unieke styleienskappe wat die outeur onderskei, en dat dié stylelemente (soos herhaling en veral drievoudige herhaling, ironie, die gebruik van getalle en lyste, en kontras) deur die hele boek, insluitende die visioene, voorkom. In ' $n$ volgende punt sal teruggekom word na redaksiehistoriese hipoteses oor die gebruik van twee tale.

\subsection{Refleksie op helleniseringsbeleid}

Hilton (1995:110) se teorie is dat die twee tale ' $n$ geheime refleksie is op Antiochus se helleniseringsbeleid. Dieselfde gebeur met die twee name wat aan Daniël toegedig word. Die twee name en twee tale word gebruik om implisiet Antiochus se beleid te kritiseer. Die argument word dan gebruik dat die skrywer die verwarring wat Antiochus in die Jood se wêreld ingedra het, deur sy gebruik van twee tale beskryf.

\subsection{ABA-struktuur}

Gordon (1958:83) en Lenglet (1972:171) meld dat die Hammurabiwetgewing (Kode 9) op die ABA-struktuur gebou is, met die vorm gedigwet-gedig. Ook Job gebruik die ABA-struktuur, in die vorm van die boek as prosa-gedig-prosa. In dieselfde sin, lui die argument, moet die struktuur van die Daniëlboek in terme van die ABA-struktuur verstaan word, in die gebruik van die tale, Hebreeus-Aramees-Hebreeus.

\subsection{Aramees as oorspronklike taal}

Ginsberg (1948:251) is van mening dat die hele Daniëlboek in Hebreeus geskryf is. Die gedeeltes wat in Hebreeus oorgelewer is (1:1-2:4a asook 812 ) is vertalings vanuit Aramees. Ginsberg meld nie om watter rede(s) die vertaling gedoen sou wees nie. Slegs die gebed van Daniël in 9:4-20 is oorspronklik in Hebreeus (Ginsberg 1948:256). Hierdie gedeelte word 
deur talle navorsers as ' $\mathrm{n}$ sekondêre byvoeging beskou (bv Charles 1929:226-227; Hartman \& Di Lella 1978:245-246).

\subsection{Gebruik van Aramees in mond van Aramese sprekers}

' $n$ Laaste verduideliking wat vir die gebruik van twee tale aangebied word, is dat die wyse manne die koning "in Aramees" geantwoord het. Hierdie siening is deur Hieronimus gepopulariseer (Charles 1929:29). Die veronderstelling is dat die toespraak noodwendig in die hoftaal sal wees (Le Roux 1995:13). Die hoftaal is egter Babilonies of Assiries (Hammer 1976: 27), soos blyk uit Jeremia 5:15, Jesaja 28:11 en 33:19. Dit is ' $n$ fout om te meen dat Aramees aan die Babiloniese hof gebesig is (Hammer 1976:6). Nie almal stem saam met Hammer nie. Ander (bv Baldwin 1978:29 en Le Roux 1995:13) meen Aramees volg Akkadies teen die einde van die agtste eeu vC as wêreldtaal van die Ou Nabye Ooste op. 2 Konings 18:26 kan ook in dié rigting wys.

Die probleem is dat nie slegs die sterrekykers en Babiloniese koning se woorde in Aramees weergegee word nie, maar die res van die boek tot aan die einde van Daniël 7 (Aalders s.a.:29). Daarmee saam moet onthou word dat die verdeling van die boek op grond van die gebruik van taal nie met die vormkritiese verdeling van die boek, in verhale en visioene, ooreenstem nie.

Nie een van die vermelde verduidelikings is werklik bevredigend nie. In die res van die artikel sal ' $n$ hipotese voorgestel en ontwikkel word wat poog om ' $\mathrm{n}$ meer bevredigende antwoord te bied. Voor die vraag beantwoord kan word, moet eers gevra word na die ontstaan van die boek.

\section{ONTSTAAN VAN DIE DANIËLBOEK}

Daar bestaan drie teorieë oor die ontstaan van die Daniëlboek (Niehr $\left.1998^{3}: 461\right)$. Die eerste hipotese beweer dat die boek as 'n eenheid aan die hand van "n enkele skrywer ontstaan het ("Einheitshypothese"). Hierteenoor staan die fragmente-hipotese, wat meen dat die boek uit losstaande fragmente bestaan wat langs mekaar geplaas is ("Fragmentenhypothesen"). "n Variasie op die fragmente-hipotese is die opstapelingshipotese of "Aufstockungshypothese", wat aanvaar dat die boek uit fragmente bestaan, maar dat daar " $n$ geskiedenis in die groei van die boek van enkele fragmente tot die uiteindelike produk bestaan. Die meeste nuwe hipoteses oor die ontstaan van die Daniëlboek berus op die opstapelingshipotese. 
Die drie hipoteses hou verband met die Skrifbeskouing wat die onderskeie navorsers gebruik. Die leser wat die Bybel as die Woord van God beskou wat tot die laaste Hebreeuse vokaalteken geïnspireer is, het geen ander keuse as om alles letterlik te vertaal en te interpreteer nie (Spangenberg 1998:33). Vir dié leser het die Bybel objektiewe gesag wat in die waarheid en historisiteit van sy verhale gedemonstreer word. Dié leser beskou die Daniël-verhale as werklike gebeurtenisse in die lewe van vier Joodse jongmanne. Hierdie vier Jode is letterlik in $606 / 5 \mathrm{vC}$, tydens ' $\mathrm{n}$ beleg wat nie in die Bybel beskryf word nie, deur Nebukadnesar na Babel weggevoer. Hier het Daniël vir die volle duur van die ballingskap aan die hof van verskeie heidense konings diens gedoen. Die ballingskap was letterlik sewentig jaar omdat Jeremia geskryf het dat dit sewentig jaar sal wees. Dit vorm die eenheidshipotese.

Die fragmente- en opstapelingsteorieë hou verband met die voorkoms van talle historiese onakkuraathede in die Daniëlboek. Die historiese onakkuraathede klaar al meer op sodra die skrywer nader aan sy eie tyd, die tweede eeu, beweeg. Die navorser beskou die Daniëlverhale (Dan 1-6) as ou legendes, wat deur die tweede eeuse skrywer oorvertel is om iets binne sy eie konteks te sê. So praat Coxon (1993:214) van verskillende siklusse van verhale wat rondom die lewe van Daniël sentreer en ten minste in die tweede eeu in sirkulasie was. Die eerste deel van Daniël bestaan dus uit verhale wat voorheen om ander redes vertel is. " $n$ Joodse skrywer het dit in die tweede eeu $\mathrm{vC}$ nuut geïnterpreteer om sy Joodse tydgenote binne hul spesifieke historiese krisis te bemoedig. Die bemoediging van die verhale bestaan daarin dat Israel se God in beheer is, dat Hy soewerein regeer. Sy volk is nie an die genade oorgelaat nie, omdat Hy in sy genade verantwoordelikheid vir hul lot aanvaar. Die tweede deel, die visioene (Dan 7-12), staan in diens van dié teologiese veronderstelling, om die geskiedenis as toekomsvoorspelling te beskryf. Die doel daarvan is om aan te toon dat God alle historiese prosesse haarfyn beplan en beheer.

Die fragmente- en opstapelingshipoteses, wat ook soms die Makkabeërhipotese genoem word, is eers sedert 1890 aan Duitse universiteite bekend. Dit is buite Duitsland deur die Protestante sedert die einde van die Eerste Wêreldoorlog, en deur die Rooms Katolieke ná die Tweede Wêreldoorlog gepropageer. Die standpunt het in Suid-Afrika meer onlangs eers begin veld wen (Koch 1980:9; Spangenberg 1998:23). 
Een van die hoekstene van die Christelike getuienis in die eerste twee eeue van die kerk se bestaan was die vervulling van profesie. "If the prophecies are not true, Christianity is not true. To destroy the prophets is to destroy Christ" (Criswell 1968:23). Dit is in dié omstandighede dat Porfirie, ' $\mathrm{n}$ filosoof wat sy Christelike geloof volgens Hieronimus afsweer, reeds vanuit die Oosterse kerk in die derde eeu (saam met ander Siriese kerkvaders) ' $n$ Makkabese ontstaanstyd vir die boek voorstel. Ook Uriel Acosta, ' $n$ sewentiende eeuse Joodse rasionalis, en Anthony Collins (in die agtiende eeu) bou hul argumente oor die interpretasie van die boek op die Makkabeërhipotese (Young 1949:23).

Indien hierdie hipotese waar is, beteken dit dat die Daniëlboek (in sy finale weergawe) die laaste boek is wat in die Ou Testament opgeneem word (Rendtorff 1985:276).

Niehr (19883:461-2) stel voor dat die ontstaan van die Daniëlboek langs die volgende lyne verloop het:

Die verhale in Daniël 1-6 vorm die oudste deel. Dié verhale het vroeër ' $n$ Babiloniese konteks gehad. Die skrywer benut dit in die tweede eeu $\mathrm{vC}$ as hy die Daniëlboek saamstel, en die verhale op sy nuwe konteks toepas. Hy brei die verhale uit met die visoene (Dan 7-12). Daniël 1 word uit die Aramees vertaal as ' $n$ inleiding tot die res van die boek terwyl Daniël 7 as brug tussen die verhale en visioene aangewend word. Die eerste ses hoofstukke kom dus uit die oosterse Diaspora, en die laaste sewe hoofstukke uit Jerusalem van die tweede eeu.

Die wysheidsvertellinge in Daniël 4-6 dateer uit die vyfde of vierde eeu vC. Die twee vertellinge handel oor die wyse en regverdige Daniël (Dan 4:1-24, 31-34 en 6:1-29), en die ondergang van Babiloniese wêreldheerskappy (Dan 4:25-30 en 5:1-30).

Niehr (19983:462) se slotopmerking is belangrik en som die huidige stand van die debat in: "Beim derzeitigen Forschungsstand ist es zu früh, ein Fazit aus den laufenden Diskussionen zur Entstehung des Danielbuches zu ziehen".

\section{HIPOTESE}

Die vraag wat deur die gebruik van twee tale gestel word, is: vorm die Daniëlboek ' $n$ eenheid? Dié vraag hou direkte verband met die ondersoek na die ontstaan van die boek (sien 6 hierbo). Indien die samesteller bloot materiaal uit verskillende bronne geleen het, maak dit sin as hy/sy nie die 
moeite gedoen het om dit in een taal te vertaal nie. Daar kan geredeneer word dat die skrywer moontlik nie taalvaardig genoeg was om dit te doen nie.

Daar is reeds geredeneer (by 5.6) dat die eenheid van die boek gehandhaaf word, alhoewel dit nie noodwendig beteken dat die samesteller vir al die verhale en visioene verantwoordelik was nie (so ook o a Van Beek 1962:764 en Helberg 1994:16). Die samesteller het wel redaksionele bywerkings gedoen, soos duidelik gesien kan word in die unieke styleienskappe wat die outeur onderskei. Dié stylelemente sluit in herhaling, en veral die gebruik van drievoudige herhaling, ironie, die gebruik van getalle en lyste, en kontras (vgl ook Burden 1987:206-8 en Niehr 19983:460 wat vanuit ' $n$ bespreking van die opbou van die boek daarop wys dat die boek ' $n$ eenheid vorm). Hierdie elemente kom regdeur die boek voor, en sluit die verhale en visioene in.

Indien dit die geval is, dring die volgende vraag hom aan die navorser op: indien die samesteller materiaal uit ' $n$ bron of bronne geleen het, hoekom het hy/sy nie dit vertaal en as " $n$ eenduidige dokument aan sy/haar lesers aangebied nie?

Eissfeldt (1974:527) se gevolgtrekking is korrek: navorsers het geen ander alternatief as om te aanvaar dat die skrywer verantwoordelik is vir die gebruik van twee tale nie. Wat was sy/haar rede om die boek in twee tale aan te bied?

Die antwoord wat Eissfeldt (1974:528) en Burden (1987:206) aanbied, is dat die skrywer as model die boeke van Esra en Nehemia gebruik, wat in Hebreeus geskryf is, maar (Persiese) ryksdokumente in Aramees aanhaal (om legitimiteit daaraan te verleen). Die probleem is egter dat alles in Aramees nie die gevolg is van woorde wat in die mond van Babiloniese sterrekykers geplaas word nie. Trouens, een van die visioene is ook in Aramees (Dan 7:1-28).

Eissfeldt (1974:528) meen die beste argument vir die voorkoms van twee tale in die boek is om te erken dat die antwoord nie bekend is nie: "An explanation of the double language which is entirely satisfactory has not yet been proposed by anyone". Davies (1985:35) stem daarmee saam: "The presence, and the distribution, of the two languages in Daniel may be in the end inexplicable". Bentzen (1952:9) kom tot dieselfde gevolgtrekking: "Ein trotz aller daran gewendeten Mühe immer noch ungelöstes Rätsel bleibt der Sprachwechsel ...". 
'n Belangrike vraag in dié verband is: hoe het die samesteller se eerste uitgawe van die boek gelyk? Hier is daar soveel argumente as moontlikhede. Sommige meen die hele boek is in Hebreeus geskryf, maar die oorspronklike het nie in die verwarring wat met Antiochus se vervolging gepaard gegaan het, behoue gebly nie (om enkele navorsers te noem wat dié standpunt onderskryf, vgl Aalders s.a.:30; Montgomery 1927:92; Monsma 1957:153; en Koch 1980:49). Nog ander meen die boek het in Aramees ontstaan, en sommige gedeeltes is vir Hebreeuse lesers vertaal, of die Hebreeuse vertaling van die boek het vir ' $n$ onbekende rede langs die Aramese oorspronklike beland (Young 1949:22; Knight 1971:436; Eissfeldt 1974:516 en LaCocque 1979:13). En dan is daar sommige wat meen dat die boek aanvanklik, en doelbewus, in twee tale ontstaan het (Collins 1977:15; Hilton 1995:110).

Dit is belangrik om te onthou dat die woorde "in Aramees" ook in die Qoemrandokumente voorkom, wat immers die oudste manuskripte is wat daar van die boek bestaan (Davies 1985:35; Lucas 2002:19,63). Agt framente van manuskripte van die Daniëlboek is by Qoemran ontdek. Die oudste, 4QDan(c), dateer uit die tweede eeu $\mathrm{vC}$, en die jongste uit die laaste fase van die bewoning van Qoemran, in die eerste eeu nC. Die Hebreeuse en Aramese verdeling van die boek kom net so voor in die kopieë wat by Qoemran ontdek is. Die verandering van Hebreeus na Aramees in 2:4b asook die verandering van Aramees na Hebreeus kom by 4QDan ${ }^{\mathrm{a}}$ asook 4QDan(b) voor.

Tog is dit waarskynlik dat " $n$ oorskrywer die woorde "in Aramees" in Daniël 2:4a vanuit 'n kantlynaantekening, wat die leser van die taalverandering wou waarsku, in die teks invertaal het. Dit moes op 'n baie vroeë stadium reeds gebeur het, soos die Qoemrandokumente toon.

Onder navorsers is daar groeiende konsensus dat die verhale hul oorsprong in die Diaspora van die Persiese periode het (bv Hammer 1976:7). Die etos en inhoud daarvan veroorsaak dat dit nie in die tweede eeu vC geplaas kan word nie. Daarvoor is die beeld wat van heidense konings, en van die verhouding tussen Jode en heidense konings geteken word, veels te positief. ' $\mathrm{n}$ Ander (en beter) plek en tyd word daardeur geteken. En dit ignoreer die belangrikste kwessies in die Makkabese periode, soos die (Antiocheense verbod op) Sabbatsonderhouding en besnydenis. Daarmee saam maak Hartman \& Di Lella (1978:13) die waarneming dat die talle korrekte en ingeligte verwysings na gebruike en terme wat direk aan die 
Persiese hof herinner, die verhale teen die agtergrond van die sesde eeu plaas.

Hoekom is die verhale oorvertel? Humphreys (1973:211) is korrek as hy meen die oorspronklike doelwit met die verhale was om ' $n$ geskikte leefstyk vir Diaspora-Jode voor te stel.

Lucas (2002:314) stel voor dat die hele boek in die oosterse Diaspora ontstaan het, insluitende die visioene. Hy argumenteer dat die dierebeelde van Daniël 7 en 8 asook die vorm van die profesie in Daniël 11 aan 'n oosterse oorsprong herinner. Die verhale dateer uit die vroeë Persiese periode en funksioneer onder ' $\mathrm{n}$ groep welgestelde, opgevoede Jode wat deels in beroepe in die uitgebreide Persiese staatsdiens gestaan het. Die verhale moedig hulle aan om na sukses in hul sekulêre beroepe te streef terwyl hulle getrou aan die God van hul voorvaders bly. Op dié manier eer hulle JHWH onder die heidene.

Die etos van die visioene is duidelik verskillend van die verhale (Burden 1987:213). Moontlik het dit te doen met die subjektiewe belewenis wat die skrywer gehad het in die ervaring daarvan. Dit hou egter ook verband met die verskil in die lewenssituasie en -omstandighede van die groep tot wie die visiene gerig is. Toegepas op die Antiocheense oorlewingskrisis maak die visioene sin. Die wêreldbeeld van die verhale, waar suksesvolle diens aan die heidense koning en getrouheid aan die Joodse God as versoenbare doelwitte gestel word, het in die nuwe situasie verval. Die Jood verwag nou dat 'n nuwe koninkryk sal aanbreek waarin Jode wat getrou aan God gebly het, die leidende rol sal vervul. So vorm die visioene die ervaringsbasis van ("n groep) Jode wat poog om hul situasie te verstaan en sin daarvan te maak (Niditch 1980:163; Rowland 1982:243).

Waar die stories deel van die tradisie gevorm het wat die selfbegrip van Jode gevorm het, is die apokaliptiese wêreldbeeld van die visioene ' $n$ ontwikkeling van die wêreldbeeld van die verhale, gebaseer op die Jode se nuwe ervarings en behoeftes (Birch et al 1999:446). Dit kan die duidelikste gesien word in die wyse waarop die visioen van hoofstuk 7 die teologie van die geskiedenis van die verhaal in hoofstuk 2 ontwikkel (Hammer 1976:7). Sosiologiese studies van millenialistiese bewegings het duidelik die verandering in die wêreldbeeld van sulke groepe gedokumenteer (bv Cook 1995). Apokaliptiese verbeelding (John Collins se term) verskaf "a template by means of which people in many periods can understand what 
is going on around them. It allows individuals, particularly of they are part of a group that suffers, to comprehend the source of their plight" (Birch et al 1999:446).

Die verhale het in Aramees ontstaan omdat dit die gebruikstaal van die Persiese Diaspora-Jood was. Die visioene ontstaan later, in kringe waar godsdienssuiwerheid beklemtoon word, en word in Hebreeus geskryf omdat die sakrale taal aan godsdienssuiwerheid gekoppel word. Hebreeus was geskik vir esoteriese materiaal. Die visioen in hoofstuk 7 is egter in Aramees geskryf, of uit Hebreeus na Aramees vertaal omdat dit die droom van hoofstuk 2 duidelik verder ontwikkel en toepas vir die nuwe omstandighede. Op dié manier verbind die samesteller/skrywer doelbewus volgens dié hipotese die visioene aan die verhale. Hoofstukke 2-7 vorm 'n goed gestruktureerde geheel. Hoofstuk 1 staan buitekant die eenheid en vorm ' $n$ goeie inleiding deur die leser aan die karakters en situasie in die boek voor te stel. Die skrywer wat die boek saamstel, is verantwoordelik vir die inleiding voor hy/sy die Diaspora-verhale aanwend as wyse om sy/haar lesers aan te moedig, voor hy/sy by die visioene kom wat sy/haar eie werk is.

Daniël 1 kon geredelik in Aramees bestaan het, soos Koch (1980:17) duidelik aandui as hy gemaklik die verhaal in Aramees vertaal.

Die bedoeling wat die skrywer met die boek gehad het, om tweede eeuse Jode moed in te praat tydens die bedreigings wat Antiochus IV se helleniseringsbeleid vir hul voortbestaan ingehou het, word immers primêr in die laaste gedeelte van die boek aangetref, veral in die laaste visioen wat van Daniël 10 tot 12 strek en oor "die verbondsvolk in die eindtyd" handel ${ }^{2}$.

' $n$ Sleutel tot die gebruik van twee tale kan dus gevind word in die redaksiehistoriese prosesse wat rondom die ontstaan en oorlewering van die boek afgespeel het. Vir die moderne navorser is dit moeilik om te raai hoe dié prosesse presies verloop het, maar dit is duidelik dat die boek in ten minste twee kontekste, 'n vroeë Aramese en latere (tweede eeuse) Hebreeuse, gefunksioneer het. In die oorlewering van die boek is verskeie dele saam gevoeg, en die skrywer(s)/redakteur(s) het besluit om die twee tale te behou.

2 So die indeling en opskrif van die NAB. 
Daar is ook goeie gronde om te aanvaar dat "in Aramees" die fout van 'n oorskrywer was. ' $n$ Kantlynaantekening wat die leser moes waarsku dat die taal van dié punt af verander is in die teks oorgeskryf. Nou lees die teks asof die sterrekykers die koning in Aramees antwoord.

\section{SINTESE}

Die benutting van twee tale in die Daniëlboek is nie toevallig nie. Die verskynsel kan nie op vormkritiese gronde verklaar word nie. Die oorsaak moet eerder in die redaksiehistoriese prosesse gesoek word wat agter die oorgelewerde teks lê. In dié artikel word die hipotese gestel dat die samesteller van die boek ouer materiaal gebruik uit die oosterse Diasporasituasie wat deel van die Jood se tradisies is, as agtergrond waarteen hy/sy ' $n$ nuwe wêreldbeeld ontwikkel wat deur die nuwe omstandighede, die Antiocheense krisis, vereis word.

\section{Literatuurverwysings}

Aalders, G Ch s.a. Daniël (Korte verklaring van de heilige Schrift). Kampen: Kok.

Ackroyd, P R 1953. Criteria for the Maccabaean Dating of the Old Testament. Vetus Testamentum 3, 113-132.

Anderson, R A 1984. Signs and wonders. Grand Rapids, MI: Eerdmans (ITC).

Baldwin, J G 1978. Daniel. Leicester: Inter-Varsity Press, (Tyndale Old Testament Commentaries).

Bentzen, A $1952^{2}$. Daniel. Tübingen: Mohr (Handbuch zum Alten Testament).

Bevan, A A 1892. A short commentary on the Book of Daniel. Oxford: Clarendon.

Birch, B C et al 1999. A theological introduction to the Old Testament. Nashville: Abingdon.

Burden, J J 1987. Die boek Daniël, in Burden, J J \& Prinsloo, W S (red), Tweegesprek met God. Die literatuur van die Ou Testament. Kaapstad: Tafelberg, 195-220.

Charles, R H 1929. A critical and exegetical commentary on the book of Daniel. Oxford: Clarendon Press.

Collins, J J 1977. The apocalyptic vision of the book of Daniel. Missoula: Scholars Press, Harvard Semitic monographs 16.

-, 1991. Genre, Ideology and Social Movements in Jewish Apocalyptic, in Collins, J $\mathrm{J} \&$ Charlesworth, J H (eds.), Mysteries and revelations. Sheffield: JSOT, JSPSUP 9, 11-32.

-, 1993. Daniel. Minneapolis: Fortress (Hermeneia).

Cook, S L 1995. Prophecy and apocalypticism. Minneapolis: Fortress. 
Coxon, P W 1993. Another look at Nebuchadnezzar's madness, in Van der Woude, A $\mathrm{S}$ (ed), The book of Daniel in the light of new findings. Leuven: Leuven University Press, 211-222.

Criswell,W A 1968. Expository sermons on the book of Daniel. Vol 1. Grand Rapids: Zondervan.

Danby, H 1933. The Mishna (Translated from the Hebrew with Introduction and Brief Explanatory Notes). Oxford: Oxford University Press.

Davies, P R 1985. Daniel. Sheffield: JSOT Press (Old Testament Guides).

De Villiers, P G R 1987. Leviatan aan 'n lintjie. Woord en wêreld van die sieners. Pretoria: Serva.

Eissfeldt, O 1974. The Old Testament. An introduction. The history of the formation of the Old Testament (Translated by P R Ackroyd). Oxford: Basil Blackwell.

Ginsberg, H L 1948. Studies in Daniel. New York: Jewish Theological Seminary of America.

Gordon, C H 1958. The World of the Old Testament. Roma: Pontificium Institutum Biblicum.

Hammer, R 1976. The book of Daniel. Cambridge: Cambridge University Press (The Cambridge Bible Commentary).

Hartman, L F \& Di Lella, A A 1978. The book of Daniel. Garden City, NY: Doubleday.

Helberg, J L 1994. Die boek Daniël. Die heerskappy behoort aan God. Kaapstad: N G Kerk-Uitgewers.

Hilton, M J 1995. Babel reversed - Daniel chapter 5. Journal for the Study of the Old Testament 66, 99-112.

Humphreys, W L 1973. A life-style for the Diaspora: A study of the tales of Esther and Daniel. Journal of Biblical Literature 92, 211-223.

Knight, G A F 1971. The book of Daniel, in Layman, C M (ed). The interpreter's onevolume commentary on the Bible. (Including all the books of the Old and New Testament and the Apocrypha, together with forty-three general articles). London: Collins, 436-450.

Koch, K 1980. Das Buch Daniel. Under mitarbeit von Till Niewisch und Jürgen Tubach. Darmstadt: Wissenschaftliche Buchgesellshaft (Erträge der Forschung. Band 144).

LaCocque, A 1979. The book of Daniel. (Translated by David Pellauer). London: SPCK.

Lenglet, A 1972. La Structure Littéraire de Daniel 2-7. Biblica 53, 169-190. 
Le Roux, C 1995. Profeet en politiek. Daniël. Die Woord vir die mense. Halfway House: Orion.

Lucas, E 2002. Daniel. Leicester: Apollos (AOTS 20).

Monsma, J A 1957. Daniël de profeet. Het wonderlijke panorama van de tijden der heidenen. Driebergen: Het Zoeklicht.

Montgomery, J A 1927. A critical and exegetical commentary on the book of Daniel. Edinburgh: T \& T Clark (The International Critical Commentary).

Niditch, S 1980. The visionary, in: Nickelsburg, G W E \& Collins, J J (eds), Ideal figures in Ancient Judaism. Chico, CA: Scholars (HSM 30), 153-179

Niehr, H 1998³. Das Buch Daniel, in Zenger, E et al, Einleitung in das Alte Testament. Stuttgart: Kohlhammer (Kohlhammer Studienbücher Theologie), 458-464.

Rendtorff, R 1985. The Old Testament. An Introduction. (Translated by J Bowden). London: SCM.

Rowland, C 1982. The open heaven. London: SPCK.

Rowley, H H 1955. The composition of the book of Daniel. Some comments on professor Ginsberg's article. Vetus Testamentum 5, 272-276.

Spangenberg, I J J 1998. Perspektiewe op die Bybel. God se Woord in mensetaal. Pretoria: J L van Schaik.

Terry, M S 1974. Biblical hermeneutics. A treatise on the interpretation of the Old and New Testaments. Grand Rapids: Zondervan.

Thomas, D W (ed) 1958. Documents from Old Testament Times. Leiden: Brill.

Tripolitis, A 2002. Religions of the Hellenistic-Roman age. Grand Rapids: William B Eerdmans.

Van Beek, G W 1962. Daniel, in Buttrick, G A (ed), The Interpreter's Dictionary of the Bible, Vol 1. Nashville: Abingdon, 761-769.

Young, E J 1949. A commentary on Daniel. London: The Banner of Truth Trust (Geneva Series of Commentaries). 